\title{
DROUGHT STRESS AND THE DISTRIBUTION OF VEGETATIVE AND REPRODUCTIVE TRAITS OF A BEAN CULTIVAR
}

\author{
Abelardo Nuñez Barrios $^{1 *}$; Gerrit Hoogenboom²; Dennis Scott Nesmith ${ }^{2}$ \\ ${ }^{1}$ Instituto Nacional de Investigaciones Forestales y Agropecuarias - Ave. Homero 3744, Fracc. El Vergel, 31100, \\ Chihuahua, Chih., México. \\ ${ }^{2}$ University of Georgia - 1109 Experiment Street, Griffin GA, USA. \\ *Corresponding Author <nuneza10@hotmail.com>
}

\begin{abstract}
Soil water deficits may affect the location and pattern of flower and pod production on different stem axes of a bean plant. The objective of this study was to understand the effect of drought stress on the distribution of flowers and pods on the main stem and on branches of bean plants. The experiment was conducted in a shelter field facility. Water stress was imposed from the end of the vegetative stage to physiological maturity and soil water was measured with a neutron probe every two weeks. Formation of flowers at each node of the main stem was monitored at 44 days after planting (DAP) and formation of pods at 55DAP and 65 DAP. Dry weight of stems and leaves as well leaf area were measured during the middle of the pod filling stage (55DAP). The total number of flowers reached maxima of 32 and 44 flowers per plant for the drought and irrigated treatments, respectively. Number of flowers on branches decreased $50 \%$ in the stress treatment when compared to the control. Pod setting was also reduced on the branches of the lower nodes of the main stems. Under drought, the leaf area diminished by $60.1 \%$ and $10.4 \%$ on branches and main stem, respectively. The field drought conditions of this experiment had a greater effect on the vegetative and reproductive growth of branches as compared to the main stem affecting the final yield.
\end{abstract}

Key words: dry beans, soil water, flowers, pod setting, branches

\section{STRESS HÍDRICO E A DISTRIBUIÇÃO DE CARACTERÍSTICAS VEGETATIVAS E REPRODUTIVAS DE UM CULTIVAR DE FEIJÃO}

\begin{abstract}
RESUMO: Défices de água no solo podem afetar a localização e o padrão de produção de flores e vagens em diferentes ramos de uma planta de feijão. O objetivo deste trabalho foi o de compreender o efeito do stress hídrico na distribuição de flores e de vagens no tronco principal e nos ramos de plantas de feijão. O experimento foi conduzido em ambiente controlado. O Stress hídrico foi imposto a partir do fim do estágio vegetativo até a maturidade fisiológica e a umidade do solo foi medida por meio de sondas de nêutrons à cada duas semanas. A formação de flores em cada nó do ramo principal foi monitorada aos 44 dias após semeadura (DAP), na formação de vagens aos 55 DAP e a 65 DAP. Mediu-se o peso seco de ramos e folhas, bem como área foliar, no estádio de enchimento de grãos (55 DAP). O número total de flores alcançou os máximos de 32 e 44 flores por planta para os tratamentos com stress e irrigado, respectivamente. O número de flores em ramos decresceu de $50 \%$ no tratamento de stress, em relação ao controle. O pegamento de vagens foi também reduzido nos ramos dos nós mais baixos do tronco central. Sob falta d'água a área foliar diminuiu de $60.1 \%$ a $10.4 \%$ em ramos e tronco principal, respectivamente. As condições de stress hídrico neste experimento tiveram um efeito maior nos crescimento vegetativo e reprodutivo dos ramos, em comparação com o tronco principal, afetando a produção final.

Palavras-chave: feijão, água no solo, flores, pegamento de vagens, ramos
\end{abstract}

\section{INTRODUCTION}

Drought stress is a main constraint to agricultural production including terminal stresses observed in low rainfall areas of the world where dry bean is an important crop. Soil water deficits that occur during the reproductive growth are considered to have the most adverse effect on crop yield (Costa-Franca et al., 2000; Baigorri et al., 1999). Several studies have shown that water deficits imposed during the reproductive development of dry beans can decrease the number of flowers, pods and num- ber of seeds per pod (Xia, 1997; Loss \& Siddique, 1997). The total number of flowers in some varieties may be reduced up to $47 \%$ under drought conditions affecting the number of pods per plant. However pod setting itself may also vary among dry bean cultivars in response to water deficits. Pod abortion under stress has been observed in a range between 21 and 65\% (Mwanamwenge et al., 1999; Wein et al., 1973). In general, the number of pods per plant seems to be the yield component that is most affected by drought stress during flowering and can reduce final grain yield up to $70 \%$ depending on the dura- 
tion and intensity of the stress period (Lopez et al., 1996). On the other hand, the number of seeds per pod of dry beans seems to be a more consistent yield component under drought stress and seed size variation has been reported to be of minor importance (Xia, 1997; Farah, 1981). However, less is known about the impact of drought stress on the distribution of flowers and pods of different nodes and plant axes. It is also not clear how an increase in soil moisture deficit under terminal stresses might affect the dynamics of the reproductive traits and the relationship with vegetative growth of main stems and branches of short term-determinate varieties. The objective of this research was to investigate, under field conditions, the effect of terminal water stress on the distribution of vegetative and reproductive traits between the main stem and branches of a determinate dry bean variety.

\section{MATERIAL AND METHODS}

This study was conducted at the field soil-water laboratory of the Kellogg Biological Station at the Michigan State University, USA dry bean plants (Phaseolus vulgaris L.) were grown in the field under an automatic rainout shelter facility that was used to fully control water inputs and drought stress treatments. The experimental area under the rain out shelter was totally protected during rainfall events. The shelter close and opens automatically before and after each rainfall, as described by Martin et al. (1988). The experimental unit consisted of a plot of six rows, $6 \mathrm{~m}$ long with an inter-row spacing of $0.71 \mathrm{~m}$, each plot with an independent control system for irrigation. A completely random design was used with five replicates per treatment. The field consisted of a sandy Psmmentic Hapludalf of $1.5 \mathrm{~m}$ depth. A short season dry bean variety (cultivar Seafarer) was used. This genotype was selected because it yields well under drought conditions and seems to be adapted to rainfall patterns with scarce water at the end of the season, known as terminal drought stress condition. Seeds were planted in excess and thinned after emergence to a density of 16 plants $\mathrm{m}^{-2}$. Fertilizer was applied along rows at rates of 120-100-100 (N- $\left.\mathrm{P}_{2} \mathrm{O}_{5}-\mathrm{K}_{2} \mathrm{O}\right)$. Nitrogen fertilizer was split in two applications, at planting and 20 DAP. The irrigation system, as described by NeSmith et al. (1990) operated three times per week to keep soil water content of the irrigated control close to the drained upper limit (field capacity)during the entire growing season. Irrigation for the stress treatment stopped at 27 DAP initiating a terminal water deficit from the end of the vegetative stage to physiological maturity. To monitor soil water, aluminum tubes were installed down to the $1.7 \mathrm{~m}$ depth, in the central row of each plot, and measurements were made using a neutron probe. Soil water content was measured at five depths $(0.25,0.50,0.75,1.0,1.25$ and $1.5 \mathrm{~m})$ in two-week interval. During flower initiation, ten plants per treatment were tagged to measure changes in the total number of flowers including the main stem and branches. Flowers of the tagged plants were counted in a non-destructive way every other day to characterize the dynamics of total flowering. To describe the distribution of flowers on the main stem and branches, ten plants per treatment were tagged and flowers were counted on each node at almost full flowering (44DAP). The first node on the main stem was considered as the one with the first trifoliate leaf (node zero the one with the unifoliate leaves). Twenty additional plants per treatment were randomly selected to measure the effect of the two different water regimes on pod setting at 55 and 65 DAP. Pods were counted after they reached a length of one or more centimeters. To determine the impact of drought stress and irrigation on the vegetative growth of the main stem and branches, an area of about $0.25 \mathrm{~m}^{2}$ (4 plants per plot) were sampled at 55 DAP to measure both, leaf area and dry matter production. The leaves were separated from the main stem and branches and leaf area was determined with a leaf area meter (Licor 3600). The plant components were placed in paper bags and oven dried at $70^{\circ} \mathrm{C}$ for 72 hours and the data for the four plants were averaged to obtain leaf area and dry matter per plant per plot. At the end of the season, 20 plants per treatment (four plants per replication) were sampled for estimating the average number of pods per plant, seeds per pod and weight of individual seeds. For total dry matter production and final yield, an area of $4 \mathrm{~m}^{2}$ per plot was harvested at the end of the season. Seed yield is reported at $12 \%$ of seed moisture and all data were statistically analyzed using analysis of variance

\section{RESULTS AND DISCUSSION}

The changes in soil water content over time for the drought stress treatment are shown in Figure 1. The water deficit started on 27 DAP with a rapid depletion of soil water in the top $0.75 \mathrm{~m}$ layer. After 55 DAP, most of the soil water of this treatment was absorbed from depths below $0.75 \mathrm{~m}$. By the end of the season (69DAP), no major changes in soil water content were observed, indicating that plants have reached the lower limit of water availability (permanent wilting point). For the irrigation treatment, moisture in the top $1.5 \mathrm{~m}$ of soil profile was kept near to the drained upper limit or field capacity $\left(0.16-0.18 \mathrm{~cm}^{3} \mathrm{~cm}^{-3}\right)$ for the entire growing season (data not shown).

The drought stress treatment slightly hastened flower initiation and decreased the total number of flowers per plant as observed in Figure 2. The total number of flowers reached a maximum of 32 and 44 flowers with a daily increase of 2.3 and 3.8 flowers per plant. Day for the drought and irrigated treatment respectively. The dis- 
tribution of flowers along the main stem and branches was observed at almost full flowering (44 DAP) as shown in Figure 3. For both treatments, all flowers for the first 4 nodes were located on branches and they were the most affected by the drought stress. For branches growing out of the first node of the main stem, the number of flowers decreased by $51 \%$ as compared to the irrigated treatment. For branches of the second and third node the number of flowers decreased on the average $45 \%$. Flowers above node number 4 were located on the main stem and there was no difference between the two treatments. Mwanamwenge et al. (1999) reported that the total number of flowers per plant for several dry bean varieties could be reduced up to $47 \%$ under drought conditions and, as it can be seen in the current research, the main effect may be located on branches of the lower nodes. The distribution of pods was also affected by the soil moisture deficit. At 55 DAP, most of the water was depleted from the top $0.75 \mathrm{~m}$ soil layer and this increasing drought condition induced a further effect on pod setting for both, main stem and branches. From 55 DAP to 65 DAP almost $100 \%$ of the pods were aborted from the branches
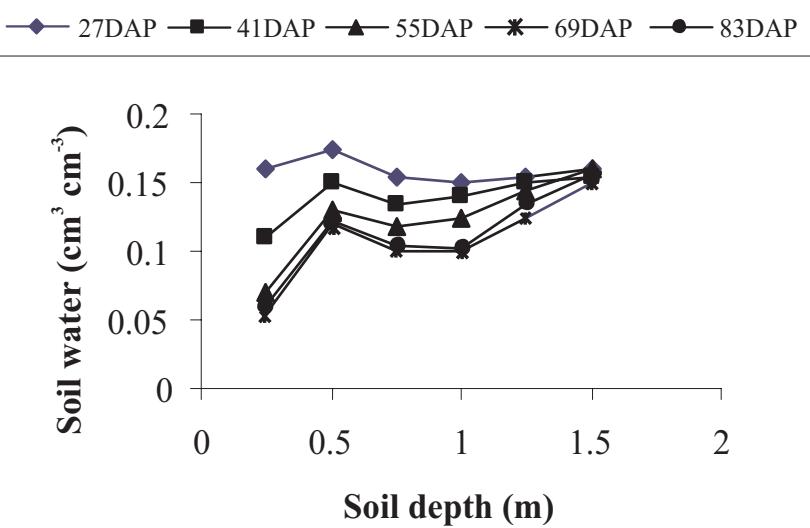

Figure 1 - Changes in volumetric soil water content in the drought stress treatment for dry beans. Kellogg Biological Station, Michigan, 1999.

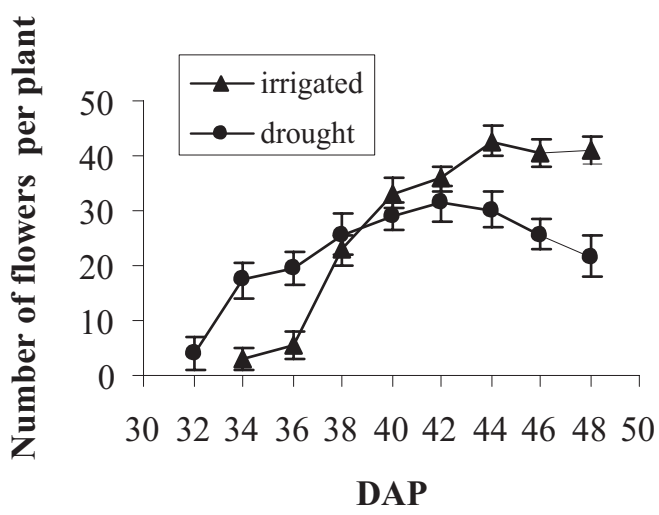

Figure 2 - Dynamics of the total number of flowers of dry beans under irrigated and drought conditions. Kellogg Biological Station. Michigan,1999.

Sci. Agric. (Piracicaba, Braz.), v.62, n.1, p.18-22, Jan./Feb. 2005 located on the first four nodes of the main stem. From node 5 to 10 pod abortion reached only an average of $15 \%$ during the same period (Figures 4 and 5).

Under stress, the decrease on the number of flowers and pods for some legumes, such as soybeans, is due to a great extent to a limited vegetative growth (Board et

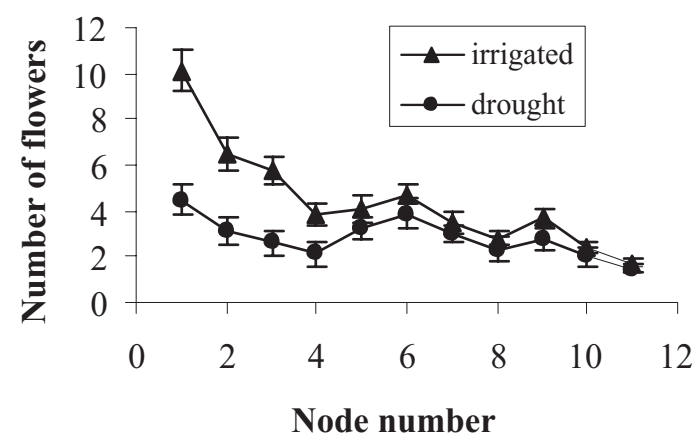

Figure 3 - Flower setting on the different nodes of the main stem for dry beans All flowers on the lower nodes (node 1-4) were located on the branches and from node 5 to 10 on the main stem.. Kellogg Biological Station, Michigan, 1999.

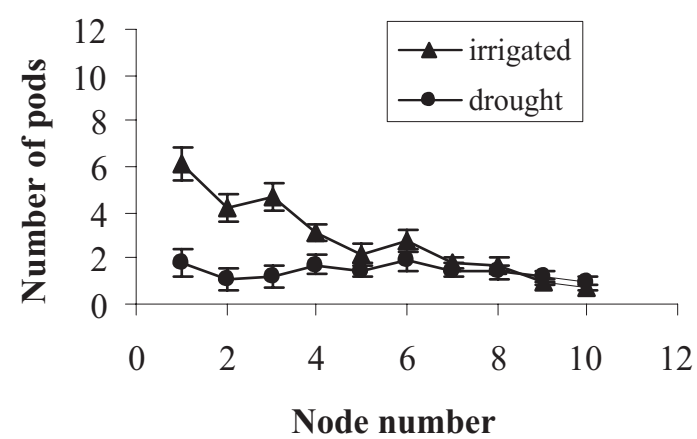

Figure 4 - Pod distribution in dry bean on different nodes of the main stem at the pod filling stage (55DAP). Pods of the lower nodes (node 1-4) were located on branches and from node 5 to 10 on main stem. Kellogg Biological Station, Michigan, 1999.

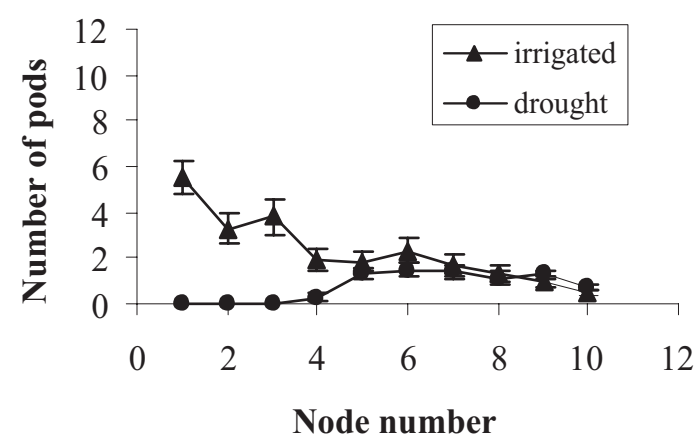

Figure 5 - Pod distribution in dry beans on different nodes of the main stem at the end of the Pod filling stage (65DAP). Pods of the lower nodes (node 1-4) were located on branches and from node 5 to 10 on main stem. Kellogg Biological Station, MI, 1999 . 
Table 1 - Dry weight and leaf area of the main stem and branches of dry beans at pod filling stage (55DAP). Kellogg Biological Station, Michigan1999.

\begin{tabular}{|c|c|c|c|c|c|c|}
\hline \multirow{2}{*}{ Treatment } & \multicolumn{2}{|c|}{ Stems dry wt. } & \multicolumn{2}{|c|}{ Leaves dry wt. } & \multicolumn{2}{|c|}{ Leaf area } \\
\hline & Main stem & Branches & Main stem & Branches & Main stem & Branches \\
\hline & - & $\ldots-\ldots g$ & nt - - - & $\ldots \ldots$ & 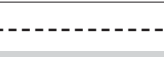 & - \\
\hline Irrigated & $1.90 \mathrm{a}^{1}$ & $3.21 \mathrm{a}$ & $1.94 \mathrm{a}$ & $3.43 \mathrm{a}$ & $469.2 \mathrm{a}$ & $1115.8 \mathrm{a}$ \\
\hline Drought & $1.58 \mathrm{~b}$ & $1.83 \mathrm{~b}$ & $1.65 \mathrm{~b}$ & $1.50 \mathrm{~b}$ & $420.6 \mathrm{~b}$ & $390.5 \mathrm{~b}$ \\
\hline Decrease & $16.9 \%$ & $43.0 \%$ & $15.0 \%$ & $56.3 \%$ & $10.4 \%$ & $60.1 \%$ \\
\hline
\end{tabular}

${ }^{1}$ means followed by same letters within a column are not different at $P<0.05$.

Table 2 - Final yield and yield components of dry beans grown under irrigated and drought Conditions. Kellogg Biological Station, Michigan 1999.

\begin{tabular}{|c|c|c|c|c|c|}
\hline Treatment & Pods per plant & Seed per pod & Seed size & Seed yield & Harvest index \\
\hline & & \multicolumn{4}{|c|}{ 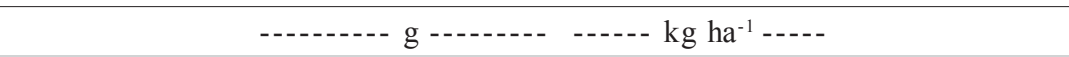 } \\
\hline Irrigated & $16.1 \mathrm{a}^{1}$ & $4.5 \mathrm{a}$ & $0.17 \mathrm{a}$ & 1989 a & $0.39 \mathrm{a}$ \\
\hline Drought & $5.9 \mathrm{~b}$ & $3.2 \mathrm{~b}$ & $0.13 \mathrm{~b}$ & $385 \mathrm{~b}$ & $0.29 \mathrm{~b}$ \\
\hline Decrease & $63.3 \%$ & $28.9 \%$ & $22.3 \%$ & $60.2 \%$ & $25.7 \%$ \\
\hline
\end{tabular}

${ }^{1}$ means followed by same letters within a column are not different at $P<0.05$.

al., 1990; Remseur et al., 1984; Xia, 1994). The effect of the soil moisture treatments on dry weight of branches and main stems is shown in Table 1. Under stress, the dry weight of stem-branches was reduced by $43.0 \%$ as compared to $16.9 \%$ of the main stem. Dry weight of leaves located on branches was reduced by $56.3 \%$ as compared to $15.0 \%$ for the leaves located on the main stem. Leaf area was also limited by the drought condition in both, main stem and branches. Under stress, leaf area in the main stem was reduced by $10.4 \%$ as compared to the reduction of $60.1 \%$ observed in branches. Stress occurring from initial flowering to the pod filling stage might affect pod setting and yield through a reduction of the vegetative growth of branches located in the lower nodes of the main stem (Board \& Harville, 1998; Linkemer et al., 1998) and good correlations have been shown between branch vegetative growth and final yield (Frederick et al., 2001)

Limiting the vegetative growth of branches may decrease the source /sink relationship between leaves and pods. Mauk \& Breen (1986) found for snap beans that $34 \%$ of ${ }^{14} \mathrm{C}$ assimilates translocated from a labeled leaf was recuperated in the nearby inflorescence as compared to $2 \%$ recuperated on a distant raceme node. Tanaka \& Fujita (1979) also showed that most of the photosyntates of a given leaf ended up in the flowers, pods and axis of the same leaf. They also claimed that flowers and pods growing nearby smaller leaves tended to abscise.

The effect of drought stress on flowering and pod setting on the different plant axes had influence on yield and yield components, as shown in Table 2. The yield component mostly affected during the stress period was pods per plant with a reduction $63.3 \%$ as compared to
$28.9 \%$ and $22.3 \%$ observed on seeds per pod and weight of seeds, respectively. The decrease in yield of grain legumes grown under drought conditions is largely due to the reduction in the number of pods per plant (Muchow, 1985; Lopez et al., 1996; Pilbeam et al., 1992). However, when soil moisture reaches the lower values of available soil water the number of seeds per pod and the weight of individual seeds may play an important role in diminishing the harvest index and final yield. Seed yield and harvest index were reduced by $80.2 \%$ and $25.7 \%$, respectively.

The drought stress imposed in this study affected the vegetative growth of both, main stem and branches of the dry bean plants, however branch growth was the most affected, limiting significantly the number of flowers, pods and final yield. This indicated that branch growth may be and important trait that may be used by plant breeders to achieve higher yield in determinate dry bean varieties.

\section{REFERENCES}

BAIGORRI, H.; ANTOLINI, M.C.; SANCHEZ-DIAZ, M. Reproductive response of two morphological different pea cultivars to drought. European Journal of Agronomy, v.10, p.119-128, 1999.

BOARD, J.E.; HARVILLE, B.G. Late-planted soybean yield response to reproductive source/sink stress. Crop Science, v.38, p.763-771, 1998.

BOARD, J.E.; HARVILLE, B.G; SAXTON, A.M. Branch dry weight in relation to yield increase in narrow-row soybean. Agronomy Journal, v.82, p.540-544, 1990.

COSTA-FRANCA, M.G.; THI, A.T.; PIMENTEL, C.; PEREYRA, R.O.; ZUILY-FODIL, Y.; LAFFRAY, D. Differences in growth and water relations among Phaseolus vulgaris cultivars in response to induced drought stress. Environmental Experiment Botany, v.43, p. 227-237, 2000.

FARAH, S.M. An examination of the effect of water stress on leaf growth of field beans; crop growth and yield. Journal of Agricultural Science, v.96, p.327-336, 1981. 
FREDERICK, J.R.; CAMP, C.R.; BAUER, P.J. Drought stress effects on branches and main stem seed yield and yield components of determinate soybean. Crop Science, v.41, p.759-763, 2001.

LINKEMER, G.; BOARD, J.E.; MUSGRAVE, M.E. Water logging effects on growth and yield components in late planted soybeans. Crop Science, v.38, p.1576-1584, 1998

LOPEZ, F.B.; JOHANSEN, C.; CHAUHAN, Y.S. Effect of timing of drought stress on phenology, yield and yield components of a short-duration pigeon pea. Journal of Agronomy \& Crop Science, v.177, p.311-320, 1996.

LOSS, S.P.; SIDDIQUE, K.H.M. Adaptation of faba bean (Vicia faba, L.) to dry land Mediterranean-type environment. I. Seed yield components. Field Crops Research, v.54, p.17-28, 1997.

MAUK, C.S.; BREEN, P.J. Partitioning of ${ }^{14} \mathrm{C}$-photosyntate among competitive sinks during flowering and early fruiting in snap beans. Journal of American Society of Horticultural Science, v.111, p.416421, 1986.

MARTIN, E.C.; RITCHIE, J.T.; REESE, S.M.; LOUDON, T.L.; KNEZEK, B. A large area light weight rainout shelter with programmable control. American Society of Agricultural Engineering, v.31, p.1440-1444, 1988.

MUCHOW, R.C. Phenology, seed yield and water use of grain legumes grown under different water regimens in a semiarid tropical environment. Field Crops Research, v.11, p.81-97, 1985.

MWANAMWENGE, J.; LOSS, S.P.; SIDDIQUE, K.H.M.; COCKS, P.S. Effect of water stress during floral initiation, flowering and podding on the growth and yield of faba bean (Vicia faba L.). European Journal of Agronomy, v.11, p.1-11, 1999.
NESMITH, D.S.; MILLER, A.; RITCHIE, J.T. An irrigation system for plots under a rain shelter. Agricultural and Water Management, v.17; p.409-414, 1990.

PILBEAM, C.J.; AKATSE, J.K.; HEBBLETHWAITE, P.D.; WRIGHT, C.D. Yield production in two contrasting forms of spring-sown faba beans in relation to water supply. Field Crops Research, v.29, p.273-287, 1992.

REMSEUR, E.L.; WALLACE, S.U.; QUINSBERRY, V.L. Distribution patterns of yield components in 'Braxton' soybeans. Agronomy Journal, v.76, p.493-497, 1984.

TANAKA, A.; FUJITA, K. Photosynthesis and yield components in relation to grain yield of the field beans. Journal of the Faculty of Agriculture. Hokkaido University, v59, p.145-238, 1979.

WEIN, H.C.; SANDSTED, R.F.; WALLACE, D.H. The influence of flower removal on growth and seed yield of Phaseolus vulgaris L. Journal of the American Society for Horticultural Science, v.98, p.45-49, 1973.

XIA, M.Z. Effect of soil drought during the generative development phase of faba bean (Vicia faba L.) on photosynthetic characters and biomass production. Journal of Agricultural Science, v.122, p.67-72, 1994.

XIA, M.Z. Effect of soil drought during the generative development phase on seed yield and nutrient uptake of faba bean (Vicia faba L.). Australian Journal of Agricultural Research, v.48, p.447-451, 1997.

Received September 18, 2003

Accepted November 04, 2004 